\title{
ОТРИЦАТЕЛЬНЫЙ АЛЬФА-ЭФФЕКТ И КОМПЬЮТЕРНЫЙ ДИЗАЙН НОВЫХ ЛЕКАРСТВЕННЫХ ВЕЩЕСТВ
}

\author{
Е.Н.Офицеров \\ Кафедра химии и технологии биомедицинских препаратов РХТУ \\ им. Д.И. Менделеева, Россия, г. Москва, Миусская пл., д. 9.
}

DOI: 10.19163/MedChemRussia2021-2021-171

E-mail: ofitser@mail.ru

Соединения, имеющие амбидентные системы Э-Э (Э = O, N, P, S и другие) с НЭП, отличаются по своей реакционной способности и биологической активности при внешне схожем скелете. Известно увеличение нуклеофильности и скоростей реакций при переходе от алкоксианиона AlkO- к аниону AlkO-O-, хотя, исходя из представлений химии, изменения должны протекать в противоположном направлении. Это явление получило название альфа- или $\alpha$-эффекта, который по своей природе является динамическим, т.е. его развитие происходит при движении комплекса реагентов по координате реакции. Однако, существуют соединения, имеющие те же атомы, но отличающиеся уникальной устойчивостью в реакциях, сопровождаемых гетеролизом связей. Можно привести в качестве примера молекулу артемизина с фрагментом О-О. Такие соединения обладают противоположным эффектом (отрицательный альфа-эффект или - $\alpha$-эффект [1]), имеющим в отличие от положительного эффекта другую природу, а именно, статическую, что и проявляется в исходном соединении. Другой пример - липоевая кислота, с одной стороны, и диалкил-дисульфиды - с другой. Тот же эффект характерен и для растительных антимикробных цистеинбогатых протеинов с четным числом остатков цистеина, которые образуют S-S связи, обеспечивая конформационную стабильность молекул и уникальные химические и биологические свойства.

Подобные примеры есть и в химии фосфора. Так, различия в спектрах четырех- и пятичленных полифосфинов и их поведение можно объяснить наличием - $\alpha$-эффекта: для тетрафосфинов - альтернирующее чередование трансрасположения заместителей и НЭП Р, для пентафосфина - как минимум, две НЭП всегда находятся в заслоненном положении. Именно это заслоненное положение и вносит изменения в поведение и различные свойства. Оба приведенных эффекта относят к типу стереоэлектронных взаимодействий, которые практически не учитываются при компьютерном дизайне новых лекарственных средств и построении зависимостей «структура-свойство» типа QASR. В докладе обсуждаются проблемы дескрипторов, отражающих стереоэлектронную составляющую.

\section{Литература}

[1] Е.Офицеров и др. О природе и роли отрицательного альфа-эффекта в химии, биохимии и токсикологии, Межд. симп. «Биохимия - основа наук о жизни», Казань, 2013, Сб. трудов симпозиума, С. 110-112. 